\title{
Badacz jako Obcy w terenie Proces wżywania się w środowisko lokalne na podstawie dzienników badań terenowych
}

\section{Researcher as The Other in The Field The process of growing into local social environment, based on field research diaries}

\begin{abstract}
A B S TRAC T: The article presents selected challenges, problems and doubts related to conducting field research in social pedagogy. They are presented from the point of view of the researcher entering the new environment. The process of getting into the environment is an indispensable element, difficult and longlasting, requiring from the researcher reliable theoretical and empirical preparation. However, without it, it is impossible to understand the context, "climate" of local values and meanings that build the studied "small homeland". The issues raised concern the adoption of an emic or etic perspective, a strategy of crossing the cognitive boundaries, and the emotional side of conducting field research. The greater part of the text is a selection from the author's personal diaries conducted during fieldwork in 2017-2019 in the bialsi poviat (Lubelskie voivodeship).
\end{abstract}

KEY Y ORDS: Social pedagogy, field studies, meeting, researcher's diaries, emic/etic perspective.

ST RES Z C Z E N I E : Artykuł przedstawia wybrane wyzwania, problemy i wątpliwości wiążące się z prowadzeniem badań terenowych w pedagogice społecznej. Przedstawione są one z punktu widzenia badacza wchodzącego do nowego środowiska. Proces wżywania się w środowisko jest elementem niezbędnym a jednocześnie trudnym i długotrwałym wymagającym od badacza rzetelnych przygotowań teoretycznych i empirycznych. 
Jednakże bez niego niemożliwe jest zrozumienie kontekstu, „klimatu” lokalnych wartości i znaczeń budujących badaną "małą ojczyznę". Poruszane zagadnienia dotyczą przyjmowania perspektywy emicznej lub etycznej, strategii przekraczania granic poznawczych oraz emocjonalnej strony prowadzenia badań w terenie. Większą część tekstu to wybór z osobistych dzienników autora, prowadzonych podczas badań terenowych w latach 2017-2019 na terenie powiatu bialskiego (województwo lubelskie).

SŁOWA KLUCZOWE: Pedagogika społeczna, badania terenowe, spotkanie, dzienniki badacza, perspektywa emiczna/etyczna, wżywanie.

\section{Badania terenowe - perspektywa emiczna i etyczna}

Nawet najlepiej przygotowany badacz, taki, który posiada dopracowane teorie, metodologie, opracował rzetelne techniki i narzędzia, plany badań, skrypty, wykresy, listy pytań, kwestionariusze i prywatne notatki musi w końcu stanąć „pod nowym niebem” środowiska, które zamierza poznawać. Jest to chwila, w której to, co bezpieczne, ułożone i skrupulatnie przygotowane nabiera niepokojącego, a zarazem ekscytującego pierwiastka przygody. Jest to moment, w którym to, co zaplanowane musi otworzyć się na nieprzewidywalne skutki spotkania z drugim człowiekiem. Świadomość wystawienia własnych badań na działanie przypadku, znaczenie „pierwszego wrażenia”, potrzeby odnalezienia drogi do nawiązania dialogu z rozmówcami, zdobycia ich zaufania, ryzyko odrzucenia i w rezultacie niepowodzenia niosą ze sobą niepokój. Wątpliwości dotyczą tego, czy wystarczy umiejętności społecznych i komunikacyjnych, doświadczenia i przebojowości, żeby zapukać do cudzych drzwi? (Hammersley, Atkinson 1995; Kaufmann 2010).

Prowadzenie badań terenowych i wchodzenie do nowego środowiska niesie ze sobą konieczność pogodzenia dwóch różnych strategii poznania. $\mathrm{Z}$ jednej strony, warunki prowadzenia badań naukowych wymagają zachowania zewnętrznego spojrzenia, obiektywizmu, uogólniania i postępowania wedle ustalonych procedur. Z drugiej, uchwycenie specyficznego kontekstu i lokalnych znaczeń wymaga niejako spojrzenia na świat „oczami tubylców”. W antropologicznym opisie strategie te określane są jako etic oraz emic. Rozróżnienie to zostało wyprowadzone w 1954 roku przez Kennetha Lee Pikea (z fonologicznych pojęć phonetic i phonemic). Perspektywa etyczna (zewnętrzna) opisuje zachowania członków badanej kultury czy wspólnoty z uprzywilejowanej pozycji, odnosząc je do ogólnego, teoretycznego modelu. Koncentruje się na zewnętrznych, mierzalnych wskaźnikach, które mogą być oceniane przez porównanie $\mathrm{z}$ innym kulturami. Natomiast perspektywa emiczna (wewnętrzna) opisuje zachowania z poziomu uczestników danej wspólnoty, a konstrukty teoretyczne wyprowadzane są $\mathrm{z}$ wnętrza tejże kultury. Dąży do ukazania 
systemu jako integralnej całości. Badania jakościowe umożliwiające zebranie materiału do analizy w tej perspektywie to najczęściej szerokie, długotrwałe obserwacje (w tym także obserwacje uczestniczące), wywiady, analiza tekstów, które ostatecznie może dać badaczowi wgląd w „tubylcze” spojrzenie na świat (Walczak 2009).

Obie przedstawione strategie poznania niosą ze sobą bagaż zalet i zagrożeń. Przyjęcie ścisłej postawy etycznej daje pewność zachowania wiarygodności naukowej, wolnej od subiektywnych ocen, za cenę niemożności dotarcia do specyficznego kontekstu badanej kultury, niedopuszczenia przez badanych do elementów najważniejszych, najbardziej prywatnych. Skrajna postawa emicza, w której język i kategorie badawcze kształtowane są przez poznawaną rzeczywistość, niesie ze sobą ryzyko utracenia naukowej obiektywności, osmotycznego przejęcia poglądów badanych wspólnot i zbyt emocjonalnego przywiązania się do miejsca badań. Przykładem zatopienia się badacza i skręcenia ze ścieżek nauki może być Frank Hamilton Cushing, jeden z pierwszych antropologów prowadzących badania terenowe (zob. Cushing 1882, 1883, 1886, 1892, 1894; Ferguson 1992). W 1879 roku zdecydował się zamieszkać wśród Indian Zuni, aby poznawać i opisywać ich zwyczaje, wierzenia, język i kulturę. W ciągu czterech lat życia wśród Zuni przejął całkowicie ich sposób życia, nauczył się języka, odrzucił zachodni styl ubierania, brał udział w obrzędach, polowaniach, aż wreszcie został plemiennym wodzem. Tożsamość antropologa ustąpiła tożsamości indiańskiej (Walczak 2009).

Badacze społeczności lokalnej podczas pierwszego zetknięcia się z badaną wspólnotą intensywnie doświadczają granicy między tym, co jednostkowe, a tym, co społeczne. Świat w który wkraczają jest dla nich obcy, nieznany, odrębny. Granicę tę można albo utrzymać, albo przekroczyć. Utrzymanie jej wiąże się z wyjaśnianiem zastanych zjawisk za pomocą własnego języka pojęć, symboli czy znaczeń opierających się na osobistych doświadczeniach. Łatwo w tym wypadku o stereotypizację, ujawnianie się nieuświadomionych uprzedzeń oraz symboliczną obronę własnych wartości. Przekroczenie granicy możliwe jest dzięki bliskiemu spotkaniu ,ja” badacza z bytem społecznym. Inicjowane chęcią poznania, uczenia się, odkrywania tego, co nieznane, niesie ze sobą duży ładunek emocjonalny. Poprzez życzliwość, braterstwo czy przyjaźń zawiązuje się poczucie więzi. Badacz przestaje odczuwać alienację, osamotnienie, a zyskuje przestrzeń do zaangażowania i działania. Jest jeszcze inny typ granicy, którą muszą pokonać badacze społeczni. Jest to granica poznania, która odnosi się do pytań: Na ile w ogóle możliwe jest zrozumienie i wyjaśnienie bytów społecznych? Jak przekuć poznawane indywidualne sensy na znaczenia kolektywne? Jak wyjaśnić świat społeczny? (Kurantowicz 2006) 
Wejście do środowiska to coś więcej niż fizyczne pojawienie się w nim, a badania terenowe to nie tylko zaplanowane wywiady z konkretnymi ludźmi. Ogromną rolę w zrozumieniu środowiska i kontekstu życia danej wspólnoty pełni doświadczanie przestrzeni, „oddychanie powietrzem miejsca”, wsłuchiwanie się $\mathrm{w}$ rozbrzmiewające $\mathrm{w}$ nim dźwięki, dostrzeganie na pozór błahych drobiazgów przyrody, architektury, topografii, symboli. Przydrożne kapliczki, stare cmentarze, napotkane tablice informacyjne, nawet jakość dróg nieraz niemo mówią więcej niż wypowiedziane słowa. Badacz musi mieć $\mathrm{w}$ sobie coś $\mathrm{z}$ dziewiętnastowiecznego flâneura - włóczącego się bez celu po ulicach Paryża, zafascynowanego pejzażem miejskim, życiem przechodniów, odnajdującego w przestrzeni sensów głębszych niż tylko te użytkowe (Zielnicki 1999).

\section{Wżywanie się w środowisko - doświadczenia pedagogiki społecznej}

W pedagogice społecznej badania terenowe mają długą tradycję sięgającą samych początków istnienia tejże dziedziny. Już Helena Radlińska w latach 20. XX w. opracowała specjalną teorię i metodykę umożliwiającą pracownikom socjalnym pomiar, analizę i diagnozę stanu środowiska. Dogłębne poznawanie środowiska Radlińska określała mianem wżywania. Obejmowało ono badanie struktur, instytucji, historii, sieci powiązań, relacji, wartości, kanałów komunikacyjnych. Miały one służyć ukazaniu dystansu między tym, co w środowisku jest, a tym, co może się w nim pojawić, i stanowiły wstęp do pracy społeczno-edukacyjnej (Radlińska 1935).

Jednym z pierwszych projektów badawczo-edukacyjnych powstałych na fali transformacji społeczno-politycznej w Polsce był program „Pogwarki Węgrowskie”. Realizowany był w latach 1987-1991 w Węgrowie, przez Stację Badawczą Wydziału Pedagogicznego Uniwersytetu Warszawskiego. Pogwarki były comiesięcznymi spotkaniami grupy badaczy z mieszkańcami. Podczas prowadzonych rozmów $\mathrm{z}$ jednej strony poprzez perspektywę biograficzną budowany był obraz społecznego, kulturowego i gospodarczego życia miejscowości, a z drugiej, odkrywano, przywracano pamięć indywidualną, lokalną historię, historię prywatną, historię codziennego życia. Zanim odbyło się pierwsze spotkanie przygotowania badaczy, czyli proces wżywania w środowisko Węgrowa, trwał rok. Bez niego, najprawdopodobniej, niemożliwe byłoby uzyskanie takiego zainteresowania i zaangażowania mieszkańców (spotkań odbyło się w sumie 40, a liczba ich uczestników rosła na zasadzie kuli śniegowej), prowadzący nie zostaliby obdarzeni takim zaufaniem, a efekty prac nie byłyby tak bogate (Theiss 2016). 
Innymi podobnymi przykładami działań środowiskowych wykorzystujących kapitał i siły społeczne drzemiące w „małych ojczyznach”, które sięgając do korzeni, pamięci i historii lokalnej dążyły do ożywienia, aktywizacji i demokratyzacji społeczności były między innymi: „Program Lucim” (Chmielewski 1984), „Program Łazarz” w jednej z dzielnic Poznania, Ośrodek „Brama Grodzka" w Lublinie (Theiss 2001).

Badania terenowe, w których badacze poprzez zanurzenie się $\mathrm{w}$ badanej rzeczywistości starali się poznawać światy ludzkich znaczeń i wartości prowadzone były (i są nadal) także przez kolejne pokolenia pedagogów społecznych. Byli to na przykład: Marek Sass na pograniczu borowiacko-krajeńskim (Sass 2010), Kamilla Łaguna-Raszkiewicz w Białymstoku (Łaguna-Raszkiewicz 2012), Beata Anna Orłowska wśród Łemków na ziemi lubuskiej (Orłowska 2013) czy wreszcie prace Marii Mendel i jej zespołu w Gdańsku (Mendel, Zbierzchowska 2010; Mendel 2015, 2016, 2017, Mendel, Theiss 2019).

\section{Przygotowania i przebieg badań terenowych w powiecie bialskim (województwo lubelskie)}

Pierwsze zetknięcie się z nowym środowiskiem, szczególnie środowiskiem małych, zamkniętych miejscowości jest zawsze doświadczeniem trudnym. Zazwyczaj kluczowym elementem jest odnalezienie „przewodnika” („opiekuna”, „odźwiernego”) i uzyskanie od niego swoistej rekomendacji. To pierwszy krok do zdobycia zaufania. Jednak samo odnajdywanie tego, kto poprowadzi nas za rękę, niekiedy jest samo w sobie interesującym doświadczeniem (Hammersley, Atkinson 1995, s. 65). Czasem wytrychem stają się sytuacje, gesty, wypowiedziane zdania, zupełnie nieplanowane. Nigdy jednak do końca nie można być pewnym, co stanie się tym kluczem do drugiego człowieka.

Kiedy stawiałam swoje pierwsze badawcze kroki (w 2009 roku), w małej wsi Żeszczynka (gmina Sosnówka, powiat bialski, województwo lubelskie), miałam nieco ułatwione zadanie. $W$ tej miejscowości noszone przeze mnie nazwisko stanowiło pewnego rodzaju pieczątkę "Swojego”, ponieważ z Żeszczynki pochodzi rodzina mojego męża. Większość mieszkańców pamięta dziadka Stefana Odyńca (nazwisko ujawnione po pierwszych recenzjach tekstu, zgodnie $\mathrm{z}$ sugestią redakcji). Kiedy któregoś dnia pojawiłam się na progu pewnego emerytowanego nauczyciela, wskazanego mi jako „ten co to dużo wie”, w pierwszym momencie zostałam wzięta za przedstawiciela Świadków Jehowy (co udało mi się od razu sprostować). Przy drugim spotkaniu zostałam posadzona przed kartką papieru, na której napisane było Stefan Odyniec i mu- 
siałam rozpisać (z głowy!) pełne drzewo genealogiczne rodziny. Dopiero kiedy mój rozmówca odnalazł mnie na tym schemacie, odrzekł „To teraz wiem z kim rozmawiam".

Mając za sobą doświadczenie prowadzenia badań terenowych $\mathrm{w}$ regionie Południowego Podlasia i biografię środowiska jednej ze wsi - Żeszczynki, w roku 2017 powróciłam w te same okolice, żeby przystąpić do nowych badań, tym razem potrzebnych mi do pracy doktorskiej. Ponieważ wciąż byłam kimś z rodziny Odyńców, a moi dawniej zapoznani „przewodnicy” nadal deklarowali mi pomoc - miałam od czego zacząć. Jednakże projektując badania dużo szersze niż poprzednio, obejmujące teren całego powiatu bialskiego i zawierające wywiady zarówno z mieszkańcami jak i przedstawicielami władz, instytucji państwowych i samorządowych, nauczycielami, liderami i działaczami społecznymi, musiałam wyjść poza znaną mi Żeszczynkę.

Przed rozpoczęciem właściwego, pierwszego etapu badań w sierpniu 2017 roku przeprowadziłam gruntowną analizę informacji zbieranych w internecie oraz przekazywanych mi przez zaprzyjaźnionych sąsiadów w prywatnych rozmowach o funkcjonujących instytucjach kulturowo-oświatowych, działaniach samorządowych, wydarzeniach kulturalnych, imprezach okolicznościowych (dożynki, jarmarki, festiwale), miejscach ważnych historycznie oraz tych popularnych, wybieranych do spędzania czasu wolnego. Następnie wybrałam się na wstępną podróż po powiecie bialskim - zwaną przeze mnie „Wyprawą zwiadowczą". Głównym celem było nawiązanie pierwszych znajomości, przygotowanie gruntu do dalszych badań, zweryfikowania możliwości przeprowadzenia planowanych wywiadów, odszukanie „przewodników” po środowisku lokalnym, a także odwiedzenia, zobaczenia na własne oczy kluczowych, znaczących miejsc regionu. Strategia ta okazała się owocna, ponieważ - tak jak to sobie założyłam - dzwoniąc kilka miesięcy później, aby umówić się na wywiad, nie byłam dla mojego rozmówcy obcym warszawskim numerem telefonu, ale konkretną osobą, którą widział, z którą rozmawiał, której uścisnął dłoń. Także moje zorientowanie $\mathrm{w}$ tym, co się dzieje $\mathrm{w}$ regionie, na przykład znajomość większości nazw nawet malutkich miejscowości, rozeznanie w kalendarzu świąt i imprez, wyników wyborów czy głównych problemów powia$\mathrm{tu}$, niejednokrotnie spotykało się z pozytywnym zaskoczeniem i zauważalnie zmniejszało dystans między mną - badaczem a rozmówcą. Powoli, małymi krokami stawałam się coraz mniej Obca.

Przez wszystkie etapy badań (mieszkając na stałe w Warszawie prowadziłam je na zasadzie kilkudniowych wypadów w powiat bialski, w pełni poświęcając wówczas czas na prowadzenie wywiadów, kompletowanie dokumentacji fotograficznej lub uczestnictwo w wybranych wydarzeniach) prowadziłam 
dziennik, w którym starałam się jak najdokładniej zapisać nie tylko „to co mnie spotkało", ale także wszystkie swoje wrażenia, przemyślenia, sukcesy i porażki, emocje, które odczuwałam w każdym momencie, takie jak: radość, euforia, lęk, niepokój, wątpliwości czy zupełnie zwyczajne zmęczenie. Ponieważ pamięć bywa zawodna, zależało mi, żeby utrwalić w tych dziennikach obraz południowego Podlasia jaki wówczas widziałam, z najmniejszymi nawet szczegółami (krajobraz, pogoda, zapach powietrza, smaki jedzenia), jednocześnie zamknęłam w nim obraz siebie jako badacza. Fragmenty dzienników, pokazujące moje osobiste zmagania z poznawaną rzeczywistością i z samą sobą przedstawiam poniżej, w niezmienionej, reporterskiej formie.

\section{3 sierpnia 2017 - Żeszczynka}

Najtrudniej byto wyjść $z$ domu. Zdecydowanie dłużej niż było to potrzebne rozkoszowałam się poranna kawa, zbyt wiele tematów podchwytywatam $w$ rozmowie $z$ mężem i teściami. Dwa razy się przebierałam, trzy razy wracałam. Jeszcze torba, jeszcze klucze, jeszcze woda na drogę. Nawigacja, śledzenie trasy, radio. Jadę. [...]

Nie wiedziałam czego oczekiwać, nie wiedziałam czy robię to wszystko we właściwy sposób. Odsuwatam od siebie natarczywe myśli o tym, ze zmarnuje czas tak wielu zaangażowanych $w$ tę wyprawę osób, że zawiodę sama siebie nie przywożac ze soba nic konkretnego. Bo czego właściwie szukałam? Plan był tylko lekko zarysowany: pokręcić się po okolicy. Co to właściwie znaczy? Jak przy takich założeniach odróżnić sukces od porażki? W jaki sposób mam się kręcić po (tak wielkiej) okolicy, żeby nie było to tylko przejeżdżanie przez kolejne miejscowości? I wreszcie - ludzie. Czy znajde w sobie na tyle przebojowości i odwagi, żeby zagadnać obcych mi ludzi w taki sposób, żeby i oni chcieli ze mna rozmawiać? Co właściwie mam im powiedzieć? Kogo szukać? Od czego zaczaćc? O co pytać? Jak nie przegapić tego co ważne - tego co na mnie gdzieś tam czeka?

$Z$ chaosem $w$ głowie jechałam trasa stawatycka $w$ kierunku Romanowa, $w$ którym znajduje się pięknie utrzymany dwór Kraszewskiego, obecnie muzeum. $Z$ różnych tras jakie rozważałam jeszcze $w$ Warszawie, właśnie ten punkt uznałam za najlepszy na rozpoczęcie mojej wyprawy. Po pierwsze - jest to atrakcja turystyczna położona najbliżej Żeszczynki. Po drugie, jednej strony jest to znany mi teren (jeśli chodzi o park wokót dworu), ale jeśli chodzi o samo muzeum, nie było mnie $w$ nim już od lat. Po trzecie, $z$ początkiem sierpnia otworzono tu nowa wystawe czasowa - listy i pocztówki Kraszewskiego z jego licznych podróży - co wydało mi się dobrym pretekstem do odwiedzin. A po czwarte, jakoś podświadomie czułam, że dom Kraszewskiego zupetnie mnie nie peszy (nie tak jak myśl o zupetnie nieznanych mi miejscowościach). Jeśli gdzieś mam nabrać rozpędu badawczego - to właśnie tam. 
Bardzo lubię jeździć z Wisznic do Sławatycz. Szczególnie tym prawie dwunastokilometrowym, zupetnie pozbawionym zakrętów i łuków odcinkiem drogi nr 63. Szeroka jezdnia, idealnie prosta, wycelowana jak strzała z łuku prosto na wschód, ponoć miała stużyć jako pas startowy dla samolotów podczas działań wojennych. Czy to prawda? Nie wiem. Styszałam już różne wersje. Dość, że jest to pięknie położona trasa, olśniewająca płaskimi krajobrazami, przecinająca pola, łąki i lasy. Jest też zazwyczaj zupetnie pusta i aź prosi się o to, żeby przycisnać pedał gazu. Prułam więc na wschód droga krajowa numer 63. Przede mna słońce złociło rżyska po skończonych już żniwach, za moimi plecami kłębiły się sinoczarne, burzowe chmury. Skręciłam $w$ prawo, $w$ niewielka asfaltowa droge prowadzaca do miejscowości gminnej - Sosnówki. Jakość nawierzchni nie pozwalała już na galop moich koni mechanicznych. Musiałam zdecydowanie zwolnić, usiłując nie urwać zawieszenia na dziurach oraz ostrożnie mijając nielicznych rowerzystów. W Sosnówce na krzyżówce $w$ lewo $i$ znów na wschód, tym razem już przez lasy. Tuż przed Romanowem po raz pierwszy zobaczyłam tablicę AFRYKAŃSKI POMÓR ŚWIŃ, która zrobiła na mnie na tyle duże wrażenie, że zatrzymałam się, aby ja sfotografować. Jak się przekonałam już kilka godzin później, podobne znaki były jednymi z najczęściej widywanych przeze mnie na mojej trasie.

\section{4 sierpnia 2018 - Żeszczynka}

Wszyscy wyjechali. Dom opustoszał. Zostałam ja i moje rozgrzebane badania terenowe. Jest goraco, grubo ponad trzydzieści stopni i bardzo duszno. Przyroda zastygła $w$ tej niemiłosiernej spiekocie, najmniejszy nawet powiew nie porusza liśćmi na drzewach. Ptaki umilkły, tylko muchy, bardziej wściekłe niż zazwyczaj, rzucają się na oślep na moje żótte autko.

Mam godzinę czasu do wyjazdu. Cisza dzwoni mi w uszach, wreszcie mogę się przywitać z własnymi myślami. Dopiero teraz czuje, że gdzieś za moimi plecami czai się czarna, kosmata Panika, której nie zauważałam w codziennym zgiełku. Dopadaja mnie te same wątpliwości co rok temu. Wiem już, że najtrudniej jest zaczać, po raz pierwszy przekroczyć próg domu i wyjść na spotkanie przygodzie (bo przecież badania terenowe to przygoda), ale czuje większa presje niż poprzednio. Wtedy to byt tylko zwiad. Teraz musze, musze przywieźć konkrety. Czy mi się uda? Krzątam się po domu, mruczac pod nosem po co mi to było?, co ja wyprawiam? i zbieram rzeczy, które moga mi się przydać: dyktafon, zapasowe baterie, notatnik, dtugopis, telefon, ładowarka, sweter... na gwizdek mi sweter przy tej temperaturze? Muszę pozamykać okna, drzwi na werandę, zmyć naczynia. Co jeszcze? Co jeszcze? Żeby tylko o niczym nie zapomnieć.

W końcu wszystko mam gotowe. Zostało mi jeszcze trochę czasu więc siadam na schodach przed domem ze szklanka wody i notatnikiem. Nie było to może zbyt mądre, bo na zewnątrz nie dało się oddychać, ale łudzę się, że Panikę zamknęłam $w$ kuchni. Muszę się skoncentrować na najbliższym zadaniu. Musze chwile pomyśleć. Przeglądam listę pytań, starając się nauczyć się ich na pamięć, żeby nie musieć positkować się kartka 
23 sierpnia 2017 - Romanów

[...] Jednym z najważniejszych miejsc na turystycznych mapach powiatu bialskiego, a także obowiązkowym punktem $w$ każdym przewodniku jest dwór Józefa Ignacego Kraszewskiego w Romanowie. Jest to przepięknie odnowiona posiadłość, pierwotnie należąca do dóbr Sapiehów, która w 1802 roku została odkupiona od nich przez Annę i Błażeja Malskich (dziadków i opiekunów w latach dziecięcych pisarza). Kilkukrotnie przebudowywana, z powodu nie oszczędzających jej pożarów, nadal jednak utrzymana jest $w$ dworkowym stylu $z$ drugiej połowy XIX wieku. Od frontu znajduje się brama wjazdowa $z 1870$ roku. Dokoła biegnie, miejscami już mało czytelna, fosa. W prawie niezmienionej formie zachowat się także park z przełomu XVII i XVIII wieku. W głównej (ukochanej przez Kraszewskiego) alei świerkowej nadal rosna ogromne, ponad stuletnie drzewa. Te same, które szumiały dla małego Józefa. Pod jednym z tych niebotycznych drzew, ustawiona została specjalna ławeczka z postacia zadumanego pisarza, trzymającego otwarta ksiege na kolanach. Oprócz świerków znajdziemy tu również graby, jesiony i lipy. $\mathrm{Na}$ pótnocnym skraju ogrodu zachowała się dworska kaplica $w$ kształcie rotun$d y, w$ której cokół wmurowano prostokątne epitafia rodzinne. W samym dworze utworzone zostało muzeum. Romanów jest kochany zarówno przez mieszkańców okolic jak i odwiedzających go turystów.

My także uwielbiamy to urokliwe miejsce. Zazwyczaj, kiedy spędzamy urlop $w$ Żeszczynce, przyjeżḋamy na spacery do Romanowa. Przypomniało mi sie, jak zeszłej zimy również postanowiliśmy je odwiedzić. Krajobraz był wówczas jak $z$ bajki. Śnieg siegał nam po kolana, kilkunastostopniowy mróz czerwienił nosy $i$ policzki, a my $z$ dziećmi na sankach przedzieraliśmy się przez zaspy $w$ tym wiekowym parku. Zatrzymaliśmy się przy Kraszewskim, siedzacym jak zawsze w zadumie na swojej ławeczce pod świerkiem. Odśnieżyliśmy go. Jednak po chwili zgodnie stwierdziliśmy, że z goła głowa wygladał na bardziej zmarzniętego niż wcześniej. Podrzuciłam więc dzieciom szalony pomyst ulepienia mu ze śniegu czapki, szalika i reckawiczek $z$ prawdziwego zdarzenia.

Myślami wróciłam do Pani przewodnik, która właśnie przepiękna polszczyzna snuła swoja opowieść o Kraszewskim, jego rodzinie i bezgranicznej miłości do dworku w Romanowie. O tym jak wychowywat się pod troskliwym okiem babki Anny Malskiej prababki Konstancji Nowomiejskiej (Białej Babki). O pełnym ciepła domu, który ukształtował go w pierwszych latach życia, zaszczepiając miłość do ojczyzny, tradycji, historii, kultury, literatury i sztuki. O szkole w Białej Radziwiłłowej (obecnie Podlaskiej) w której się uczyt, pisał i publikowat pierwsze teksty, i o liceum $w$ Lublinie, $w$ którym piętnastoletni Józef nie otrzymał promocji do następnej klasy z matematyki, za co ojciec - Jan Kraszewski - ukarał go w najbardziej dotkliwy sposób - zabierając z tego ukochanego miejsca. O tym, jak $w$ dorosłym życiu wielokrotnie wracał tutaj, choć zawsze na zbyt krótko i o wiele rzadziej niż by tego pragną. I wreszcie o tym jak $z$ daleka śnił o domu swojego dzieciństwa (o czym nie raz wspominat $w$ swoich ksiażkach, listach i pamiętnikach). 
Przechodzac z jednej sali do drugiej, nasza przewodniczka wskazała przez okno na siedzaca $w$ parku na ławce postać Kraszewskiego i opowiedziała zabawna anegdotke, o tym jak pewnego zimowego poranka, pracownicy muzeum zastali pisarza $w$ śniegowej czapce, szaliku i rękawiczkach... Uśmiech sam pojawił się na mojej twarzy... Oczywiście od razu przyznałam się, kto był twórca tej zimowej garderoby. Zrobiło się naprawdę wesoło. Po dłuższych chwilach mocowania się $z$ telefonem i brakiem internetu, pokazałam jako dowód zdjęcia $z$ owego spaceru. Wszyscy chcieli je obejrzeć, a przewodniczka wspominała jak bardzo zachwycano się naszym pomysłem. Zrobiła się też dużo bardziej rozmowna i dzięki temu dowiedziałam się kilku ciekawych rzeczy, których nie da się przeczytać w żadnym przewodniku.

23 sierpnia 2017 - Sławatycze

[...] Wyczytałam kilka dni wcześniej w lokalnej gazecie, że ktoś na jakiejś ścianie jakiegoś budynku maluje jakiś mural z jakimiś Brodaczami. Postanowiłam go znaleźć. Nie miałam pojęcia gdzie się znajduje, ale raczej poszukiwania nie powinny być trudne. Sławatycze to typowa „ulicówka” - ciężko w niej zabłądzić. Miałam tė̇ plan zajrzeć do Urzędu Gminy, ponieważ po przestudiowaniu ich strony internetowej wygladało na to, że dużo działaja $w$ zakresie promocji kultury lokalnej $i$ oświaty. Wróciłam na trasę sławatycka, która po kilkunastu kilometrach kończy się nieco nieoczekiwanie dużym skrzyżowaniem. Na wprost jest przejście graniczne - widać dokładnie szlabany i budki strażnicze. Koniec drogi. Koniec Polski. Na lewo droga prowadzi wzdłuz Bugu do Kodnia, Kostomłotów, Terespola. Tam pojade później. Skręciłam w prawo. Sławatycze chyba najbardziej znane sa $z$ tego, że stoja w nich naprzeciwko siebie prawosławna Cerkiew i katolicki Kościół. Czyż może istnieć lepszy przykład wschodniej wielokulturowości niż te dwie, zaglądajace sobie $w$ oczy świątynie?

Zaraz za nimi znajduje się centrum wsi: sklepy po jednej stronie drogi, zadbany plac z kwietnikami i ławkami po drugiej oraz przylegajacym do niego budynkiem Urzędu Gminy. Zaparkowałam pod sklepem i natychmiast zauważyłam mural na ślepej ścianie apteki. Ku mojej radości dostrzegłam również dwie dziewczyny $z$ pędzlami i kubełkami farby. Ośmielona miłymi chwilami $w$ Romanowie, podeszłam do nich. $Z$ początku rozmowa się nie kleiła. Głównie stałam, obserwując je przy pracy, $z$ rzadka wymieniajac $z$ nimi pojedyncze zdania. Jednak okazało się, że przytrzymanie wysokiej, chybocacej się drabiny stojacej na trawie, $z$ malarka (... na górze, to doskonały sposób na przełamanie lodów. Im dłużej tam byłam, tym bardziej dziewczyny stawały się rozmowne. W końcu zupełnie przerwały prace, zeszły $z$ drabin $i$ opowiedziały mi o sobie i swoim muralu.

\section{4 sierpnia 2018 - Studzianka}

[...] Mam lekkiego stracha. Mam wrażenie, że nagle opuściła mnie cała pewność siebie, a w głowie pojawiła się wizja totalnej katastrofy. Skończyły się moje notatki, spisane pytania, nie jestem przygotowana! Muszę coś improwizować. Tak Ka- 
siu, pobawmy się $w$ reportera... w czasie badań terenowych. No najlepszy moment na udawanie... Panika puściła do mnie oko $z$ tylnego siedzenia samochodu...

Przez ciasna sień wchodzę do kuchni i nagle czuję się jak w ulu. Jest goraco, duszno, w resztkach powietrza mieszała się mnóstwo zapachów jedzenia, a wokół ogromnego stołu, który wypełnia w zasadzie całe pomieszczenie krząta się kilkanaście osób. Wszyscy mówia na raz, przekrzykując się nawzajem. ŁW wchodzi żwawym krokiem jako pierwszy (zadziwiające, jakiej prędkości można nabrać na dwóch schodach i maleńkiej sieni), przedstawia mnie i przez krótką chwilę kilkanaście par oczu spoglada na mnie z zaciekawieniem. Przyjmuja mnie bardzo miło, lecz bez specjalnych ceregieli. Szybko wracaja do swoich zajęć, a w powietrzu znów huczy od rozmów. Nie bardzo wiem co $z$ soba zrobić i jak się zachować. Żeby jak najmniej przeszkadzać krząającym się kobietom, staję w kacie kuchni jedynym miejscu, w którym między mną, oknem za moimi plecami a stołem, byt $w$ stanie ( $z$ trudem) przejść dorosły człowiek. Przez dłuższa chwile tkwię w moim kącie, chyba z którymś z moich głupawych uśmiechów, majacym ukryć zakłopotanie. Jak zahipnotyzowana wpatruje się w gaszcz rą. Jak w dziwacznym tańcu, pośród stolnic, tac, misek, kubków i talerzy, ręce te nieustannie coś gniota, mieszaja, siekaja, kroja, obieraja, tra, tuskaja, dosypuja coś lub dolewają. Powy$\dot{z} e j$, druga warstwa rąk podaje sobie przeróżne składniki. Uśmiecham się $w$ duchu. Trochę jak w magicznej kuchni. Jakby wszystko się samo robiło. Kilkukrotnie $i$ ja właczam się $w$ ten kuchenny taniec, puszczajac $w$ obieg kolejne paczki mąki, cukru, soli, bo stałam najbliżej szafki z zapasami. Ktoś wciska mi w rękę kubek goracej kawy-plujki. Przy tym upale marzyłam raczej o wodzie, ale grzecznie podziękowałam za uprzejmość. Było mi miło. Naprawdę.

W kuchni jest kilkanaście kobiet i jeden Pan Janek, którego obecność (nasz Rodzynek!) kategorycznie każa mi podkreślić kucharki. Już po kilku minutach wyraźnie widzę, że przewodzi nimi Pani Mirka. Ona zarządza kto, co robi, to ja pytaja o receptury, ona kontroluje smaki. Nastroje sa przyjazne, wszyscy duzo sie śmieja. Wyglądaja na zgranych i lubiacych się nawzajem. Co chwile padaja żarty, z których połowy nie rozumiem. Ktoś mówi mi, żebym usiadła, bo mnie nogi rozbola, ale ja wolę stać. Mam stąd dobry widok na te cuda, które dzieja się na stole.

Czas się odezwać. Przecież nie moge tu stać jak słup soli w nieskończoność. Podpytuje o szykowane potrawy, bo to wydaje mi się bezpiecznym rozpoczęciem rozmowy. Od razu otrzymuje odpowiedź. Na dożynki planowane sa: barszcz czerwony, choć wcześniej Panie myślały o chłodniku, ale prognozy pogody zapowiadaja gwałtowne ochłodzenie (aż się wierzyć nie chce), barszcz grzybowy, pierogi ruskie, pierogi $z$ soczewica, słoninę $z$ cebulka i octem, smalec z ogórkiem kiszonym, koziołki z parówek (kawałki parówek zawinięte w plaster boczku i smażone $w$ cieście). Do tego takie regionalne ziemniaki, o których już styszałam $w \dot{Z} e s z-$ czynce (ziemniaki puree formuje się łyżką na kluski i smaży na patelni). Jednocześnie pada kila nazw tej samej potrawy: lemieszki, lepiochy, gandza, prażucha - jak się okazuje - co dom to inna nazwa, az same kucharki były tym zacieka- 
wione. Tatarskie pieremiacze (sakiewki z farszem z ryby i cebuli), kartoflaniki. $\mathrm{Na}$ słodko planowane sa paczki, bułki, ciasto ze śliwkami. Dowiaduje się, że tatarskiej kuchni obecne tu członkinie stowarzyszenia uczyły się na specjalnym kursie, do prowadzenia którego zaproszono Tatarów spod Białegostoku. Dopytuję się o ich korzenie tatarskie, ale potwierdzaja mi, że Tatarów w Studziance już nie ma. Kilka lat temu zmarła ostatnia potomkini. Ale oni chca podtrzymywać pamięć o nich. Lubia to. Cenia.

[...] Rozmowa powoli schodzi na mnie. Skąd jestem, co tu właściwie robię... Cierpliwie opowiadam o rodzinie Odyńców, domu w Żeszczynce, pracy magisterskiej, dzieciach (nie chca mi uwierzyć, że mam trójkę), studiach doktoranckich, pracy badawczej. Żeszczynka znów działa jak pieczątka, znaczek, ̇̇e nie jestem aż tak bardzo obca. Ktoś ma siostrę w Żeszczynce, ktoś bywał w Żeszczynce, ktoś ma stamtąd wspomnienia (o Marianie-organiście, który pijany w sztok grał do porannej mszy). Dziwia się, że tak dużo wiem o okolicach $i$ instytucjach działajacych $w$ regionie.

[...] Z każda chwila czuje się coraz swobodniej w ich towarzystwie. Jest naprawdę sympatycznie $i$ wesoło. Rodzinnie. W pewnym momencie wyrywa mi sie, że ze mnie taki mieszczuch, $\dot{z} e$ nigdy $w \dot{z} y c i u \dot{z}$ adnego pieroga nie ulepiłam. Natychmiast zostaje posadzona do stołu, dostaje stolnice z powycinanymi kołkami ciasta i miska farszu. My Paniq raz dwa nauczymy, to mąz zadowolony będzie.

\section{5 sierpnia 2017 - Husinka}

[...] W miarę opowieści Pani Bożenny oczy robiły mi się coraz większe ze zdumienia i czułam jak wstępuje we mnie swego rodzaju euforia. Wypiłyśmy już drugi dzbanek herbaty, zjadtyśmy całe ciasto. Rozmowa oczywiście nie przebiegała $w$ tak uporządkowany sposób jak powyższy opis. Pełna była dygresji, (moich) okrzyków zachwytu (np. na widok miniaturowego bukietu papierowych hiacyntów umieszczonych $w$ połówce orzecha włoskiego), osobistych historyjek i rodzinnych opowieści z życia. W międzyczasie kilkukrotnie zmieniałyśmy pokoje. Przez pewien czas nawet siedziałyśmy na podłodze ogląając stare, czarno-białe fotografie ocalone z czyichś strychów i zapomnianych szuflad.

[...] Po czterech godzinach i wypiciu trzeciego dzbanka herbaty, pomimo zaproszenia na obiad musiałam już się zbierać $w$ dalsza drogę. Moja rozmówczyni też przecież spieszyła się do szpitala. I tak byłam zdumiona, że poświęciła mi tak dużo czasu w obliczu swojej trudnej sytuacji rodzinnej. Wymienityśmy kontakty, uściskałyśmy się serdecznie i już będąc ze soba "po imieniu”, życzac sobie jak najszybszego ponownego spotkania, wreszcie się pożegnałyśmy.

Całkowicie oszołomiona tym co mnie spotkało $w$ Husince jechałam $w$ kierunku Białej Podlaskiej. Przez głowe galopowały mi myśli, wspomnienia, obrazy i pierwsze refleksje, które próbowałam jakoś wstępnie sobie poukładać. Przede wszystkim, dominowało we mnie poczucie, że oto znalazłam miejsce, $w$ którym wszystko to, co mnie najbardziej interesuje, co najbardziej kocham (od rękodzieła, przez historię, kulturę i tradycje, po edukacje) łączy sie pod jednym dachem stuletniego dworku. 


\section{5 sierpnia 2017 - Drelów}

Postanowiłam jechać już w kierunku Żeszczynki, zbaczając pod drodze do gminy Drelów. Kilka dni wcześniej trafiłam na informację, że mniej więcej $w$ tych samych dniach, w których ja będę objeżdzać powiat bialski, w Witorożu maja trwać wykopaliska archeologiczne. W tejże wsi, znajduje się przepiękny, zabytkowy, drewniany kościót, wybudowany przez Lwa Sapiehę $w$ XVIII wieku. W czasie II wojny światowej, mieszkańcy zdjęli i zakopali gdzieś trzy dzwony, tak, aby nie zostały zabrane i przetopione przez Niemców. Jednak po wojnie, nikt nie mógt sobie przypomnieć, gdzie zostały one ukryte. W zeszłym roku, jeden z rolników przypadkowo odkopał jeden $z$ nich i tak zaczęło się „szaleństwo” poszukiwań. W kwietniu ściagnięto na pomoc archeologów, pod przewodnictwem Mieczysława Bieni. Dzwonów nie odnaleziono, ale w zamian za to badacze natrafili na ślady Gotów z II i II wieku. Teraz wrócili, dalej eksplorować ten, jak się okazało, bogaty $w$ tajemnice teren.

Nigdy nie widziałam „na żywo” wykopalisk archeologicznych, dlatego, pomimo zmęczenia, postanowiłam nie przepuścić takiej okazji. [...] Na miejsce dojechałam bez przeszkód [...]. Zaparkowałam pod zabytkowym kościołem. Przez dtuzsza chwile stałam, przyglądając się jego fasadzie, jednocześnie zastanawiając się, jak mam znaleźć teren wykopalisk. Wiedziałam, że sa na jakimś polu, ale gdzie? Szczęśliwie pojawiła się niewielka grupka nastolatek, które wskazały mi drogę (za remiza Pani pójdzie). Poszłam we wskazanym kierunku. Nie minęły trzy minuty, jak ujrzałam $w$ oddali ludzi z łopatami chodzacych po rozkopanej ziemi. Niespiesznie podeszłam do nich. Spytałam dwóch mężczyzn, którzy akurat znajdowali się najbliżej mnie, czy to tutaj prowadzone sa te badania, o których czytałam $w$ prasie i czy mogłabym chwile popatrzeć jak pracuja. Nie mieli nic przeciwko. Postałam tak dłuższa chwile, i kiedy już miałam ochote wracać do samochodu, nieco tracac nadzieję, że wydarzy się jeszcze coś ciekawego, zagadną mnie inny mężczyzna, stojący kilka metrów dalej. Okazało się, że był to sam Mieczysław Bienia - szef grupy, kierownik działu archeologicznego oraz koła naukowego Fibula w Muzeum Południowego Podlasia w Białej Podlaskiej. Pasjonata, który od ponad dwudziestu lat sukcesywnie przekopuje wschodnie rubieża Polski.

Kolejna godzinę spędziłam więc siedząc, w ciepłym słońcu, na hałdzie piachu, patrzac jak Pan Mieczysław łopata odkrawa plasterek po plasterku, kolejne cienkie warstwy ziemi i stuchałam jego bardzo ciekawych opowieści o tych terenach $z$ punktu widzenia archeologa. W pewnym momencie, napomknęłam o tym, że i ja trochę zajmuję się badaniem Południowego Podlasia. Stysząc to, aż się wzdrygnąt.

- To nie jest żadne Południowe Podlasie! To jest Północne Polesie! - trochę mnie zamurowało. Próbowałam się bronić, że tak czytałam w książkach, tak mówili mi mieszkańcy ...

- A co oni tam wiedza - wylazł z rowu, w którym stał od dłuższego czasu i końcem ekierki, na piasku zaczął rozrysowywać mi mapę Polski (zaskakujaco szczegółowa jak na użyte narzędzia) i opowiadać, co i gdzie leży. Według niego, Podla- 
sie siega wyłacznie do linii Krzny, a wszystko co jest na drugim jej brzegu, jest to (północne) Polesie. W dodatku ponoć część archeologów upiera się, że ten obszar w którym właśnie się znajdowaliśmy jest Wschodnim Mazowszem. Zagadnienie jest $w$ każdym razie sporne i budzace sporo emocji $w$ świecie nauki.

\section{5 sierpnia 2018 - Husinka}

Pogoda jest bardzo przyjemna. Nie jest upalnie, ale słońce co chwile wynurzajace się zza szybko przepływajacych chmur grzeje i ozłaca podlaskie krajobrazy. Po przekroczeniu trasy z Siedlec do Terespola przecieram oczy ze zdumienia. Powalone drzewa, wszędzie porozrzucane połamane gałęzie, część z nich wciąż leży na asfalcie lokalnych dróg, trzeba je powoli wymijać. Wyglada na to, że nawatnica, która wczoraj mnie straszyła, tutaj nie miała litości.

\section{6 sierpnia 2018 - Łomazy}

[...] postanawiam $w$ drodze $z$ Żeszczynki do Łomaz zrobić zdjęcia wszystkim krzyżom i kapliczkom jakie będę mijała. Odległość między tymi miejscowościami to $17 \mathrm{~km}$. Po ponad godzinie jazdy i dwudziestym trzecim zdjęciu dochodzę do wniosku że tego się nie da zrobić. Tym bardziej, że wiem, że część krzyży ominęłam, nie mając miejsca żeby przystanąć. Jest ich mnóstwo. Zatrzymuję się co kilkadziesiąt metrów. Krzyże i kapliczki stoja wszędzie, na polach, łąkach, na rozstajach, na skrajach lasów, pośród drzew, na prywatnych posesjach... wszędzie. A to tylko jedna droga. Moje przystawanie i robienie zdjęć chyba nie bardzo sie podobało mijanym przeze mnie ludziom. Miałam wrażenie, że niektórzy patrza na mnie podejrzliwie, a w niektórych oknach rozsuwane sa firanki. Postanowiłam, że nie będę robić zdjęć kapliczkom przy prywatnych domach.

\section{5 sierpnia 2017 - Drelów}

Odbiłam $z$ trasy wisznickiej $w$ prawo. Znów miałam to samo wrażenie co wczoraj: im dalej jechałam „w dół mapy”, tym gęściej robiło się od roślinności. Inne były te lasy - jakby bardziej liściaste. Czasem zamykały drogę $w$ zielonym tunelu. Było naprawdę ładnie i złapałam się na myślach, że jeśli miałabym $z$ jakiegoś powodu, kiedykolwiek $w$ życiu przeprowadzać się do powiatu bialskiego, to właśnie $w$ tę, południowa jego część.

\section{Podsumowanie}

Badania terenowe zajmują dużo więcej czasu niż ten przeznaczony na zaprojektowanie narzędzi, ich faktycznie przeprowadzenie (np. wywiadów) i późniejsza analiza. Są długotrwałym procesem, w którym zawiera się między innymi: własne poszukiwanie wiedzy ( $\mathrm{z}$ różnych dziedzin) na temat badanego terenu, nawiązywanie wstępnych znajomości, rekonesans w kierunku realnych możliwości przeprowadzenia badań, wżywanie się w środowisko, zdobywanie 
zaufania społeczności. Każde spotkanie z drugim człowiekiem może skutkować „otwarciem drzwi”, o których nie mieliśmy pojęcia, a które okazują się ważne w zrozumieniu specyficznego kontekstu danej kultury, regionu czy wspólnoty. Często zdarza się, że założony rozmiar badań rozrasta się, a ilość zebranego materiału przytłacza równie mocno, co świadomość tego, jak wiele zostało pominięte, jak wiele drzwi jeszcze zostało uchylonych i niewykorzystanych.

Badania terenowe to również osobiste zmagania badacza $\mathrm{z}$ samym sobą. Z jednej strony jest to przezwyciężanie własnych lęków, przekraczanie własnych granic, z drugiej, nabywanie i rozwijanie nowych kompetencji społecznych, poszerzanie swoich horyzontów. Czasem niespodziewanie zdobywa się zupełnie nowe umiejętności (jak np. lepienie tatarskich pierogów). Nabieranie doświadczenia, umiejętności radzenia sobie w nowych, zaskakujących okolicznościach, poszukiwanie płaszczyzny dialogu $\mathrm{z}$ drugim człowiekiem jest procesem niezwykle cennym i ciekawym. Jednakże śladów takiego samorozwoju badacza i wewnętrznej walki jaką musiał stoczyć próżno szukać w poważnych, ostatecznych wersjach naukowych publikacji. Te zwykle zawierają metodologiczne i techniczne informacje. Można je jednak wyczytać w prywatnych dziennikach, osobistych relacjach z prowadzonych badań (zob. np. Hammersley, Atkinson 1995; Kaufmann 2010, Theiss 2006, 2016, Kurantowicz 2006).

Prowadzenie dziennika badań, w takiej właśnie osobistej, reporterskiej formie, z dbałością o szczegóły i bez ukrywania „siebie” i swoich emocji, to coś więcej niż tylko „dowód” przeprowadzenia wywiadów. Jest materiałem umożliwiającym uczenie się refleksyjne. Refleksja jest specjalnym procesem myślowym, który nierozłącznie związany jest z praktyką, zdobywaniem doświadczeń, namysłem nad własną postawą. Jest to także zastanawianie się nad zadaniami wykonanymi i tymi do wykonania, a jej konsekwencją jest uczenie się z biografii (zarówno własnej jak i innych). Refleksyjna praktyka trwa całe życie, a według Donalda Schöna, jest elementem trwalszym i ważniejszym niż wiedza nabyta (Perkowska-Klejman 2011; Smolińska-Theiss 2013). Wracanie do zapisków, nawet po latach, umożliwia refleksyjne przyjrzenie się sobie w roli badacza, zauważenie własnej drogi rozwoju, zmiany. Pozwala dostrzec (być może wcześniej niezauważane) popełnione błędy i wyciąganie $z$ nich wniosków. Dzielenie się dziennikami pozwala innym badaczom szlifować swój warsztat, przezwyciężać poczucie osamotnienia i zagubienia w swoich badawczych zmaganiach, aż wreszcie pokazuje na wskroś edukacyjną, humanistyczną, „ludzką twarz” badań jakościowych. 


\section{Literatura}

Chmielewski W. (1984), Inspiracje i działania plastyczne w Lucimiu, „Polska Sztuka Ludowa”, nr 4.

Ferguson R.B. (1992), Yanomami - A Savage Encounter. Western Contact and the Yanomami War Complex, [w:] R.B. Ferguson, N.L. Whitehead (red.), War in the Tribal Zone: Expanding States and Indigenous Warfare (School of American Research Advanced Seminar Series), School of American Research Press, Santa Fe.

Hammersley M., Atkinson P. (1995), Metody badań terenowych, Poznań: Wydawnictwo Zysk i s-ka.

Kaufmann J-C. (2010), Wywiad rozumiejacy, Warszawa: Oficyna Naukowa.

Kurantowicz E. (2006), Badacz i mała społeczność lokalna. Proces badania jako zmaganie się $z$ granicami, [w:] M. Mendel (red.), Pedagogika Miejsca (ss. 75-90), Wrocław: Wydawnictwo Naukowe Dolnośląskiej Szkoły Wyższej Edukacji TWP.

Łaguna-Raszkiewicz K. (2012), Pamięć społeczna o relacjach polsko-żydowskich w Białymstoku. Perspektywa edukacji międzykulturowej, Toruń: Wydawnictwo Naukowe Grado.

Mendel M. (2016), Miasto pedagogiczne, „Studia Pedagogiczne”, 69.

Mendel M. (2017), Pedagogika miejsca wspólnego. Miasto i szkoła, Gdańsk: Wydawnictwo Naukowe Katedra.

Mendel M. (red.) (2015), Miasto jak wspólny pokój. Gdańskie modi co-vivendi, Gdańsk: Gdańskie Towarzystwo Naukowe.

Mendel M., Theiss W. (red.) (2019), Pamięć i miejsce. Perspektywa społeczno-edukacyjna, Gdańsk: Wydawnictwo Uniwersytetu Gdańskiego.

Mendel M., Zbierzchowska A. (red.) (2010), Tożsamość gdańszczan. Budowanie na (nie)pamięci. Gdańsk: Wydawnictwo Uniwersytetu Gdańskiego.

Orłowska B.A. (2013), Transmisja tożsamości (Studium przypadku Łemków), Strzelce Krajeńskie: Wydawnictwo Lemko Tower.

Perkowska-Klejman A. (2011), Refleksyjna praktyka jako kategoria edukacyjna, „Pedagogika Społeczna", 2, s. 61-77.

Radlińska H. (1935), Stosunek wychowawcy do środowiska społecznego, Warszawa: Nakładem „Naszej Księgarni”, sp. akc. Związku Nauczycielstwa Polskiego.

Samoraj M. (2001), Kurpie: kultura ludowa i przekazywanie dziedzictwa kulturowego, [w:] W. Theiss, Mała Ojczyzna. Kultura - Edukacja - Rozwój lokalny, Warszawa: Wydawnictwo Akademickie „ŻAK”.

Sass M. (2010), Edukacja środowiskowa na pograniczu borowiacko-krajeńskim. Zadania - zakresy - formy, Toruń: Wydawnictwo Adam Marszałek.

Smolińska-Theiss B., Edukacyjny charakter pracy socjalnej, [w:] M. Mendel, Skrzypczak B., Praca socjalna jako edukacja ku zmianie. Od edukacji do polityki, Warszawa: Centrum Wspierania Aktywności Lokalnej CAL.

Theiss W. (red.) (2001), Mała ojczyzna. Kultura, edukacja, rozwój lokalny, Wydawnictwo Akademickie „Żak”, Warszawa.

Theiss W. (2006), Góra Kalwaria/Ger: pejzaż asocjacyjny (studium pamięci kulturowej miejsca), [w:] M. Menel (red.), Pedagogika miejsca (ss. 55-74), Wrocław: Wydawnictwo Naukowe Dolnośląskiej Szkoły Wyższej Edukacji TWP.

Theiss W. (2016), Węrów: miejsce pamięci (uwagi po 25 latach), „Pedagogika Społeczna”, 3(61), s. 71-104. 
Walczak B. (2009), Antropolog jako Inny. Od pierwszych badań do wyzwań nowoczesnej antropologii, Warszawa: Wydawnictwo Naukowe Scholar.

Zielnicki R. (1999), Od pasaży do parków rozrywki. Szkic o przeobrażeniach flâneuryzmu, „Kultura Współczesna", 3, s. 99-106.

\section{Źródła internetowe}

Cushing F.H. (1882), My Adventures in Zuni, „The Century Magazine”, Vol. 215, no. 2, s. 191-208. University of Michigan (https://hdl.handle.net/2027/mdp.39015030319530).

Cushing F.H. (1883), My Adventures in Zuni II, „The Century Magazine”, Vol. 2, no. 1, s. 500-512. University of Michigan (https://hdl.handle.net/2027/mdp.39015030319530),

Cushing F.H. (1886), A Study of Pueblo Pottery as Illustrative of Zuni Culture Growth, Fourth Annual Report of the Bureau of Ethnology to the Secretary of the Smithsonian Institution 1882-1883, Government Printing Office, Washington (https://www.scribd.com/book/187359967/A-Study-of-Pueblo-Pottery-as-Illustrative-of-Zuni-Culture-Growth-FourthAnnual-Report-of-the-Bureau-of-Ethnology-to-the-Secretary-of-the-Smithsonian).

Cushing F.H. (1892), Manual Concepts: A Study of the Influence of Hand-Usage on Culture-Growth, „American Anthropologist”, Vol. 5, no. 4, s. 289-318 (https://www.jstor.org/ stable/658590?seq=1\#metadata_info_tab_contents).

Cushing F.H. (1894), Outline of Zuni Creation Myths, Thirteenth Annual Report of the Bureau of Ethnology to the Secretary of the Smithsonian Institution 1891-1892, Government Printing Office, Washington (http://www.gutenberg.org/files/48342/48342-h/48342-h.htm)

\section{Materiały niepublikowane}

Odyniec K., Wyprawa zwiadowcza czyli nigdy nie wiadomo dokąd cię nogi poniosą, dziennik badań trenowych 23-25 sierpnia 2017.

Odyniec K., Powieść drogi bez trupa i puenty czyli badania terenowe sierpień 2018, dziennik badań terenowych 24-31 sierpnia 2018. 